\title{
Fatty Acid Profiles and Tocopherol Contents of Buriti (Mauritia flexuosa), Patawa (Oenocarpus bataua), Tucuma (Astrocaryum vulgare), Mari (Poraqueiba paraensis) and Inaja (Maximiliana maripa) Fruits
}

\author{
Antonio M. da Cruz Rodrigues, ${ }^{a}$ Sylvain Darnet ${ }^{b}$ and Luiza H. Meller da Silva ${ }^{*, a}$ \\ ${ }^{a}$ Instituto de Tecnologia and ${ }^{b}$ Instituto de Ciências Biológicas, Universidade Federal do Pará, \\ 66.075-900 Belém-PA, Brazil
}

\begin{abstract}
O buriti, tucumã, inajá, mari e patauá são palmeiras endêmicas da região Amazônica. As polpas destes frutos são tradicionalmente consumidas pela população local, mas ainda não ganharam os mercados nacionais e internacionais. A composição nutricional em ácidos graxos foi determinada por cromatografia gasosa (CG) e a de tocoferol determinada por cromatografia liquida de alta eficiência (CLAE). As polpas se mostraram bastante energéticas, com um alto teor de óleo que variou entre 31,0 a 41,8\%. Os ácidos graxos que apresentaram maiores concentrações foram o oleico (C18:1) e o palmítico (C16:0), para todas as polpas estudadas. A polpa de buriti foi a que apresentou maior teor de vitamina $\mathrm{E}$ sendo considerada uma ótima fonte de tocoferol. $\mathrm{O} \alpha$-tocoferol foi o tocoferol predominante, com exceção da polpa de buriti. Os dados indicaram que as frutas estudadas são boas fontes de ácidos graxos insaturados e tocoferóis.
\end{abstract}

Amazonian fruits are rich in fat but have a fatty acid profile that may be beneficial in relation to risk of coronary heart disease. Amazonian fruits also contain other potentially cardioprotective constituents including tocopherols. Tocopherol profiles were determined by high performance liquid chromatography (HPLC), and fatty acid profiles were determined by gas chromatography (GC). In the present study, the total oil content, fatty acid composition and tocopherol content of the pulps of five Amazonian fruits (buriti, patawa, tucuma, mari and inaja) were measured. The total oil content of the fruits ranged from 31.0 to $41.8 \%$. The major fatty acid in all of the fruits was oleic acid (C18:1), though substantial levels of palmitic acid (C16:0) were present. Linoleic acid (C18:2) was the main polyunsatured fatty acid observed. $\alpha$-Tocopherol was the most prevalent tocopherol except in buriti pulp. Buriti and mari pulp have a high content in $\alpha$-tocopherols with 297 and $155 \mu \mathrm{g} \mathrm{g}{ }^{-1}$ of dry matter. Our data indicate that all five of these Amazonian fruits are good sources of unsaturated fatty acids and tocopherols.

Keywords: Amazonian fruits, fatty acids, vitamin E, Arecaceae, Icacinaceae

\section{Introduction}

The Amazonian region houses a large variety of fruit crops, some of which have potentially promising health and nutritional properties. In particular, buriti (Mauritia flexuosa), patawa (Oenocarpus bataua), tucuma (Astrocaryum vulgare) and inaja (Maximiliana maripa) have significant nutritional value and are appreciated by the population of this region. ${ }^{1}$ These fruits belong to the family Arecaceae, and are distributed throughout the Amazon and northern South America. The mesocarp is comestible and nutritious, containing high quality oil. ${ }^{2}$ Mari (Poraqueiba paraensis), belongs to the family

*e-mail: 1hmeller@ufpa.br
Icacinaceae, and is a native species, exclusive to Pará State, common throughout the estuary of the low Amazon. The mesocarp and epicarp shell are edible, and are also used to produce oil and wine. ${ }^{3}$

Amazonian fruits are rich in fat, but more than $61 \%$ of these fats are unsaturated and could be considered healthy fats with cardioprotective potential. Amazonian fruits also have high levels of tocopherols, which are present in the unsaponifiable lipid fraction of foods. ${ }^{4}$ Tocopherols are synthesized in photosynthetic microorganisms and plants and are most concentrated in plant seeds. ${ }^{5}$

Vitamin $\mathrm{E}$ is an important natural antioxidant in foods, especially those rich in polyunsaturated fatty acids. Due to its role as a scavenger of free radicals, vitamin $\mathrm{E}$ is also believed to protect the body against degenerative malfunction, 
particularly cancer and cardiovascular diseases. ${ }^{5}$ Natural vitamin $E$ is composed of eight chemical compounds: $\alpha-, \beta$-, $\gamma$ - and $\delta$-tocopherols and their corresponding tocotrienols. ${ }^{6}$ $\alpha$-Tocopherol is the most active form of vitamin $\mathrm{E}$. The $\delta$ and $\gamma$ forms of the vitamin are absorbed efficiently by the human body, but after $24 \mathrm{~h}$ the $\alpha$ form is preferentially enriched in the plasma. ${ }^{5} \alpha$-Tocopherol has the highest biological activity based on fetal resorption assays and is less susceptible to degradation than the other forms. ${ }^{7}$

Monounsaturated fatty acids (MUFAs) are the predominant fatty acids in fruits and contribute, on average, approximately $62 \%$ of the total fat. It is widely recognized that dietary fat type influences plasma cholesterol levels to a greater extent than does total fat intake. Therefore, replacing saturated fat with unsaturated fat may be more effective in lowering the risk of coronary heart disease (CHD) than reducing fat intake per $\mathrm{se}^{4}$

Several different methods for the analysis of vitamin $\mathrm{E}$ by gas chromatography (GC) as well as by high-performance liquid chromatography (HPLC) have been described in the literature. ${ }^{8}$ Traditionally, analysis of fat soluble vitamins has been performed with several methods, including solvent system extraction and/or saponification followed by liquid extraction with organic solvents like petroleum ether or hexane. When saponification followed by liquid extraction with organic solvents is used, the extraction ratio of tochocromanols (tocopherols and tocotrienols) from the saponification medium can be affected by the matrix, the extraction solvents, the saponification temperature and the presence of an antioxidant; therefore, the extraction conditions must be carefully controlled. The saponification procedure has the advantage of separating the tocochromanols from acyl lipids and transforming esters into their corresponding alcohols. This facilitates separation as well quantification via HPLC, because these analytes are easily defined as free compounds. ${ }^{9}$

\section{Experimental}

\section{Amazonian fruit samples}

Five types of Amazonian fruits were analyzed in this study: buriti (Mauritia flexuosa), patawa (Oenocarpus bataua), tucuma (Astrocaryum vulgare), mari (Poraqueiba paraensis) and inaja (Maximiliana maripa). The fruits were collected in the State of Pará in Brazil.

\section{Reagents}

Solvents (HPLC grade and GC grade) were purchased from Merck (Germany). The $\alpha, \beta, \gamma$ and $\delta$-tocopherol standards were purchased from Matreya Inc. (USA), and the fatty acids standard reference $74 \mathrm{X}$ was purchased from Nucheck (USA).

\section{Lipid extraction}

The Bligh and Dyer method ${ }^{10}$ was used to extract from dried pulp. This method is compatible with the determination of fat content in all types of liquid, semiliquid and solid foodstuffs. Additionally, the extracted lipids may be further esterified and converted to methyl esters for gas chromatographic determination of fatty acid profiles. The total lipid fraction was extracted by exhaustive maceration with chloroform and methanol. Following filtration of solids and separation of the solvent/fat layer, the fat extract was collected and then used to calculate fat percentage or to measure fatty acid methyl ester content. Generally, dried samples (10\% moisture) were used to facilitate the extraction with organic solvents.

\section{Tocopherols quantification}

Vitamin E content was quantified according Brubacher et al. ${ }^{11}$ for pulp fruits. A $1 \mathrm{~g}$ sample of dry fruit pulp was saponified under nitrogen with ethanolic potassium hydroxide $(5 \mathrm{~mL} 50 \% \mathrm{KOH} \mathrm{m} / \mathrm{v}: 30 \mathrm{~mL} 96 \%$ ethanol; $2 \mathrm{~mL} 12 \% \mathrm{Na}_{2} \mathrm{~S} \mathrm{~m} / \mathrm{v} ; 100 \mathrm{mg}$ hydroquinone) at $80{ }^{\circ} \mathrm{C}$ for $30 \mathrm{~min}$. Fat-soluble vitamins were then extracted from the saponified sample twice with $150 \mathrm{~mL}$ of stabilized diethyl ether ( $7 \mathrm{mg} \mathrm{L}^{-1}$ butylated hydroxytoluene). The organic phases were pooled and washed with $50 \mathrm{~g} \mathrm{~L}^{-1} \mathrm{NaCl}$ $(100 \mathrm{~mL})$ and water purified with a MilliQ purification system (Millipore, USA) (100 mL, several times) until a neutral $\mathrm{pH}$ was obtained. This material was then filtered and dried with a rotary evaporator at $35{ }^{\circ} \mathrm{C}$. The residue was dissolved in $10 \mathrm{~mL}$ of methanol. Vitamin E analysis was performed on a Shimadzu HPLC model LC10AT $_{\text {VP }}$ chromatograph with a pump (LC-10 AD), oven, Shimadzu SPD10AV VP UV-Visible detector, and Shimadzu RF10A XL fluorescence detector and equipped with a Gemini C18 Phenomenex $(250 \mathrm{~mm} \times 4.60 \mathrm{~mm}$, $5 \mu$ particles) reverse phase column. The mobile phase was a mixture of methanol and water $(95: 5 \mathrm{v} / \mathrm{v})$. Solution of tocopheryl acetate was used as standard reference and was subjected to extraction and HPLC under the same operating conditions as the unknown samples, but the quantities of chemicals used for saponification were $(10 \mathrm{~mL} \mathrm{KOH}$, $100 \mathrm{mg}$ hydroquinone, $25 \mathrm{~mL} 96 \%$ ethanol) and extraction (twice with $100 \mathrm{~mL}$ of diethyl ether) were slightly different. As an internal standard, $200 \mu \mathrm{L}$ of tocopheryl acetate was added to each sample and was quantified by 
UV absorption at $284 \mathrm{~nm}$. Determination of tocopherol vitamers content was performed by fluorescence detection (excitation $290 \mathrm{~nm}$, emission $330 \mathrm{~nm}$ ). Concerning tocopherol analysis, reverse phase chromatography does not distinguish between $\beta$ and $\gamma$-isomers of tocopherol, thus the sum of these isomers is shown throughout as $\beta+\gamma$-tocopherol. The conversion to $\alpha$-tocopherol equivalent units $(\alpha-\mathrm{TE})$ was obtained by multiplying with a coefficient of 1 for $\alpha$-tocopherol, 0.3 for $\gamma$ - and $\beta$-tocopherol fraction and 0.1 for $\gamma$-tocopherol. ${ }^{6}$

\section{Fatty acid profile}

The fatty acid profile was obtained by GC of the fatty acid methyl esters (FAMEs). The oils were converted to their corresponding methyl ester. The methyl esters were prepared via saponification and esterification with potassium hydroxide in methanol $\left(0.1 \mathrm{~mol} \mathrm{~L}^{-1}\right)$ and hydrochloric acid in methanol $\left(0.12 \mathrm{~mol} \mathrm{~L}^{-1}\right)$. The fatty acid methyl esters were extracted with hexane and run on a GC CP 3380 Varian gas chromatograph. The chromatograph was equipped with a CP-Sil $88(60 \mathrm{~m} \times 0.25 \mathrm{~mm})$ capillary column (Varian Inc., USA) and a flame ionization detector. Helium was used as the carrier gas. The temperature program used was as follows: $3 \mathrm{~min}$ at $130^{\circ} \mathrm{C}$; gradual heating to $220^{\circ} \mathrm{C}$ for $9 \mathrm{~min} ; 35 \mathrm{~min}$ at $220^{\circ} \mathrm{C}$. The detector temperature was $280^{\circ} \mathrm{C}$, and the injector temperature was $245^{\circ} \mathrm{C}$. The fatty acid peaks were identified by comparing retention times: a calibration curve was performed with a mixture of standard FAMEs (Nucheck 74X). Each FAME sample was analyzed in triplicate.

\section{Results and Discussion}

The total oil content of the five selected Amazonian fruits ranged from 31.0 to $41.8 \%$ : the patawa fruit had the highest oil percentage, and the mari fruit had the least (Table 1). In comparison, palm fruit pulp (E. guineensis) has an oil content of about $73 \%$ and is the most frequently used oil producing plant in the Amazon region. ${ }^{12}$

The fatty acid profile of five Amazonian fruits, as determined by capillary-column GC, is presented in Table 2. The major MUFA in all five Amazonian fruits was oleic acid (C18:1), while lesser levels of palmitoleic acid (C16:1) were also present (Table 2). Linoleic acid (C 18:2) was the major polyunsaturated fatty acid (PUFA) present, followed by linolenic acid (C18:3). Buriti and patawa had particularly high oleic acid contents (75.5 and $76.7 \%$ of total fat, respectively) compared with the other Amazonian fruits, which had oleic acid contents of about $45 \%$ (Table 2). ${ }^{12-18}$ Palmitic acid (C16:0) and stearic acid (C18:0)
Table 1. Total oil contents of five Amazonian pulp fruits (fresh weight basis)

\begin{tabular}{lc}
\hline Oil Sample & Total Oil $(\mathrm{g}$ per $100 \mathrm{~g})$ \\
\hline Buriti & $38.42 \pm 1.45$ \\
Tucuma & $38.50 \pm 0.46$ \\
Patawa & $41.78 \pm 0.39$ \\
Inaja & $35.52 \pm 0.52$ \\
Mari & $31.04 \pm 0.41$ \\
\hline
\end{tabular}

Results shown are the mean \pm standard error of the mean from three independent analyses.

were the major saturated fatty acids present in all samples (Table 2). The total levels of UFA in the five Amazonian fruits ranged from 61.6 to $81.5 \%$. Analysis of the fatty acid profile of the fruits indicates a high unsaturated/saturated ratio. The major contributing saturated fatty acids for all fruits included palmitic acid (C16:0) and in inaja pulp with traces of myristic (C14:0) and eicosanoic acid (C20:0). The highest levels of saturated fatty acid were found in the inaja and mari. The proportion of unsaturated fatty acids in patawa and buriti pulps is similar to that of olive oil, and these oils should be considered to have good nutritional value ${ }^{18}$ However, there were larger variations in the PUFA and MUFA contents of the five fruits. For example, MUFA and PUFA contents of the buriti pulp were $75.7{\mathrm{~g} 100 \mathrm{~g}^{-1}}^{-1}$

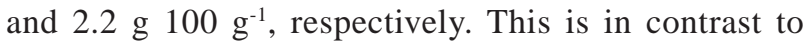
inaja pulp which contained the lowest levels of MUFAs

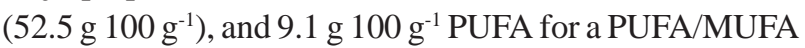
ratio of 1.7:10. This oil could also be considered as healthy and could act as a cardio protective food. ${ }^{18}$

The tocopherol contents of the five Amazonian fruits were also measured (Table 3). The levels of total tocopherol activity ranged from 22.0 to $441.0 \alpha$-TE (buriti $>$ mari > patawa > tucuma > Inaja).

$\alpha$-Tocopherol was the most prevalent tocopherol $(75.2 \%$ to $95 \%)$, except in buriti with a predominant $\beta+\gamma$ tocopherol fraction (58.3\%). Tocopherol profile of buriti pulp is similar to seed and any nut oil, as Brazil nut, walnut, mustard, pumpkin, with high content of $\beta$ tocopherol. ${ }^{19-21}$

Most plant-derived foods contain low to moderate levels of vitamin $\mathrm{E}$ activity. However, owing to the abundance of plant-derived foods in our diets, they provide a significant and consistent source of vitamin E. Photosynthetic tissues have the greatest content of tocopherols and fruit, seed and nuts have lower concentration. ${ }^{22}$ For example, determination of $\alpha$-tocopherol in tropical plants showed that in leaves the concentration could reach $800 \mu \mathrm{g} \mathrm{g}^{-1}$ of $\alpha$-tocopherol and the highest content in fruit is about $150-300 \mu \mathrm{g} \mathrm{g}^{-1}$ in pepper plants and in any nuts, as hazelnuts 
Table 2. Fatty acid composition (total \%) of oils extracted from the pulps of five Amazonian fruits

\begin{tabular}{|c|c|c|c|c|c|}
\hline & Buriti & Tucuma & Patawa & Inaja & Mari \\
\hline $12: 0$ & 0.10 & ND & ND & 3.70 & ND \\
\hline $14: 0$ & 0.10 & 0.10 & 0.10 & 7.60 & ND \\
\hline $15: 0$ & ND & ND & 0.30 & ND & ND \\
\hline $16: 0$ & 18.75 & 24.60 & 13.30 & 20.10 & 20.80 \\
\hline $16: 1$ & 0.25 & 0.10 & 0.70 & 0.10 & 0.30 \\
\hline $17: 0$ & 0.05 & 0.10 & 0.10 & ND & 0.10 \\
\hline $18: 0$ & 1.35 & 3.00 & 4.10 & 3.50 & 6.40 \\
\hline $18: 1$ & 75.50 & 65.10 & 76.70 & 52.40 & 67.60 \\
\hline $18: 2$ & 2.15 & 2.60 & 3.90 & 8.90 & 3.40 \\
\hline $18: 3$ & 0.10 & 0.20 & 0.10 & 0.20 & 0.10 \\
\hline $20: 0$ & 1.65 & 4.10 & 0.60 & 3.20 & 1.10 \\
\hline $22: 0$ & ND & 0.10 & ND & ND & ND \\
\hline
\end{tabular}

Results given are the mean \pm standard error of the mean from three independent analyses. ND means not detected.

Table 3. Tocopherol content of oil ( $\mu \mathrm{g} \mathrm{g}{ }^{-1}$ dry matter)

\begin{tabular}{|c|c|c|c|c|}
\hline & \multirow[b]{2}{*}{$\operatorname{Sum}(\alpha-T E \text { Unit })^{*}$} & $\alpha$-tocopherol & $\beta+\gamma$-tocopherol & $\delta$-tocopherol \\
\hline & & & & \\
\hline Buriti & 441.0 & $196.8 \pm 28.8$ & $476.4 \pm 28.6$ & $44.1 \pm 2.4$ \\
\hline Tucuma & 52.9 & $52.0 \pm 2.6$ & $2.8 \pm 0.2$ & Not detected \\
\hline Patawa & 59.1 & $56.5 \pm 2.9$ & $7.8 \pm 1.1$ & $7.7 \pm 0.3$ \\
\hline Inaja & 22.0 & $20.0 \pm 2.0$ & $6.6 \pm 0.4$ & Not detected \\
\hline Mari & 157.9 & $155.1 \pm 14.3$ & $9.3 \pm 1.2$ & $1.0 \pm 0.1$ \\
\hline
\end{tabular}

Results presented are the mean \pm standard error of the mean from three independent analyses. *sum in equivalent $\alpha$-Tocopherol unit ( $\alpha$-TE Unit) was obtained by multiplying with a coefficient of 1 for $\alpha$-tocopherol, 0.3 for $\gamma$ - and $\beta$-tocopherol and 0.03 for $\delta$-tocopherol. 
and almond, $310 \mu \mathrm{g} \mathrm{g}^{-1}$ and $439 \mu \mathrm{g} \mathrm{g}^{-1}$ respectively. ${ }^{19,20,23}$ $\alpha$-Tocopherol content of buriti and mari is $296 \mu \mathrm{g} \mathrm{g}^{-1}$ and $155 \mu \mathrm{g} \mathrm{g}^{-1}$ and this fruits could be considered as very rich in vitamin E. All other three fruits are good source of vitamin $\mathrm{E}$, with concentration superior of many cereals and legumes and equivalent of many nuts (peanut, walnut).

In general, tocopherol levels were in accordance with previously published values. ${ }^{15,23}$ However, inaja had a higher tocopherol content $\left(20.0 \mu \mathrm{g} \mathrm{g}^{-1}\right)$ than was previously reported by Bereau et al. ${ }^{13}$ who reported levels of $9.2 \mu \mathrm{g} \mathrm{g}^{-1}$. However, it has been reported that the fatty acid profile and phytochemical content of fruits varies between cultivars. ${ }^{24}$ This could explain the discrepancy between the two studies, as the inaja examined by Bereau et al. ${ }^{13}$ were from French Guiana and the inaja used in the present study was obtained in Brazilian Amazon region.

\section{Conclusions}

In conclusion, this study illustrates some differences in total oil, fatty acid composition and tocopherol contents between different types of Amazonian fruits. In general, however, all fruits studied have a favorable unsaturated/ saturated fatty acid ratio. Vitamin E activity levels were highest in the buriti, and the $\alpha$-tocopherol, except in buriti, was the major component in all of the fruits studied.

\section{Supplementary Information}

Supplementary information data are available free of charge at http://jbcs.sbq.org.br, as PDF file.

\section{Acknowledgments}

We acknowledge CAPES, CNPq (process 620209/ 2008-9) and FAPESPA (Fundação de Amparo a Pesquisa do Estado do Para) (process 058/2008) for financial support and fellowships.

\section{References}

1. Aguiar, J. P. L.; Marinho, H. A.; Rebêlo, Y. S.; Shrimpton, R.; Acta Amaz. 1980, 10, 755.

2. Rocha, A. E. S.; Silva, M. F. F.; Acta Bot. Brasilica 2005, 19, 657; Shanley, P.; Medina, G.; Cordeiro, S.; Imbiriba, M.; Frutíferas e Plantas Úteis na Vida Amazônica, CIFOR: Belém, Brasil, 2005.

3. Cavalcante, P. B.; Frutas Comestíveis da Amazônia, 5a ed., Coleção Adolpho Ducke, MCT/CNPq/Museu Paraense Emílio Goeldi: Belém, Brasil, 1991.
4. Brigelius-Flohe, R.; Traber, M. G.; FASEB J. 1999, 13, 1145; Traber, M. G.; Arai, H.; Annu. Rev. Nutr. 1999, 19, 343.

5. Van Eenennaam A.; Lincoln K.; Durrett T.; Valentin H.; Shewmaker C.; Thorne G.; Jiang J.; Baszis S.; Levering C.; Aasen E.; Hao M.; Stein J.; Norris S.; Last R.; Plant Cell 2003, 29, 3007.

6. Monsen, E. R.; J. Am. Diet. Assoc. 2000, 100, 637.

7. Fourie, P. C.; Basson, D. S.; Lebensm.-Wiss. u.-Technol. 1989, $22,251$.

8. Fratianni, A.; Caboni, M. F.; Irano, M.; Panfili, G.; Eur. Food Res. Technol. 2002, 215, 353.

9. Lechner, M.; Reiter, B.; Lorbeer, E.; J. Chromatogr., A 1999 , $857,231$.

10. Bligh, E. G.; Dyer, W. J.; Can. J. Biochem. Physiol. 1959, 37, 911.

11. Brubacher, G.; Müller-Mulot, W.; Southgate, D. A. T.; Methods for the Determination of Vitamins in Food, Elsevier Applied Science: Barking, Essex, 1986.

12. Bora, P. S.; Rocha, R. V. M.; Narain, N.; Moreira-Monteiro, A. C.; Moreira, R. A.; Bioresour. Technol. 2003, 87, 1.

13. Bereau, D.; Benjelloun-Mlayah, B.; Delmas, M.; J. AOAC Int. 2001, 78, 213.

14. Bora, P. S.; Narain, N.; Rocha, R. V. M.; Monteiro, A. C. D. O.; Moreira, R. D. A.; Cienc. Tecnol. Aliment. 2001, 3, 111.

15. Lubrano, C.; Robin, J. R.; Khaiat, A.; Oléagineux 1994, 49, 59. 16. Shukla, V. K. S.; Jensen, O. H.; J. Food Lipids 1996, 3, 149.

17. Yuyama, L. K. O.; Aguiar, J. P. L.; Yuyama, K.; Clement, C. R.; Macedo, S. H. M.; Fávaro, D. I. T.; Afonso, C.; Vasconcellos, M. B. A.; Pimentel, S. A.; Badolato, E. S. G.; Vannucchi, H.; Int. J. Food Sci. Nutr. 2003, 54, 49.

18. Ebong, P. E.; Owu, D. U.; Isong, E. U.; Plant Foods Hum. Nutr. 1999, 53, 209.

19. Chunhieng, T.; Hafidi, A.; Pioch, D.; Brochier, J.; Montet, D.; J. Braz. Chem. Soc. 2008, 19, 1374.

20. Ryan, E.; Galvin, K.; O'Connor, T. P.; Maguire, A. R.; O'Brien N. M.; Plant Foods Hum. Nutr. 2007, 62, 85.

21. Maguire, L. S.; O’Sullivan, S. M.; Galvin, K.; O'Connor, T. P.; O’Brien, N. M.; Int. J. Food Sci. Nutr. 2004, 55, 171.

22. DellaPenna, D.; Trends Plant Sci. 2005,10, 1360.

23. Ching, L. S.; Mohamed, S.; J. Agric. Food Chem. 2001, 49, 3101.

24. Greve, L. C.; McGranahan, G.; Hasey, J.; Snyder, R.; Kelly, K.; Goldhamer, D.; Labavitch; J. M.; J. Am. Soc. Hortic. Sci. (USA) 1992, 117, 518.

Submitted: October 21, 2009 Published online: August 3, 2010 
Fatty Acid Profiles and Tocopherol Contents of Buriti (Mauritia flexuosa), Patawa (Oenocarpus bataua), Tucuma (Astrocaryum vulgare), Mari (Poraqueiba paraensis) and Inaja (Maximiliana maripa) Fruits

Antonio M. da Cruz Rodrigues, ${ }^{a}$ Sylvain Darnet ${ }^{b}$ and Luiza H. Meller da Silva ${ }^{*, a}$

${ }^{a}$ Instituto de Tecnologia and ${ }^{b}$ Instituto de Ciências Biológicas, Universidade Federal do Pará, 66.075-900 Belém-PA, Brazil

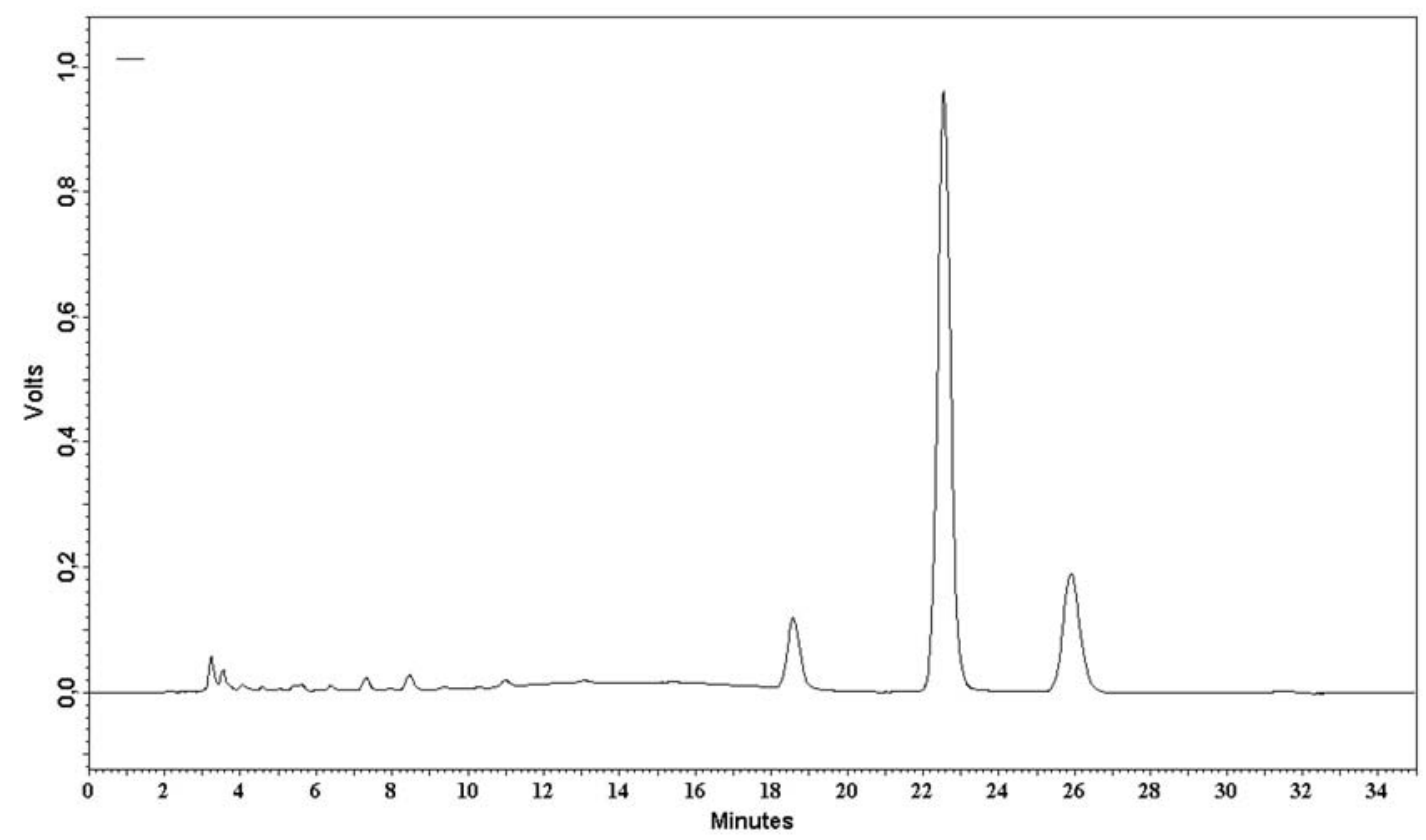

Figure S1. RP-HPLC-FLD chromatogram of tocopherols in buriti pulp. 


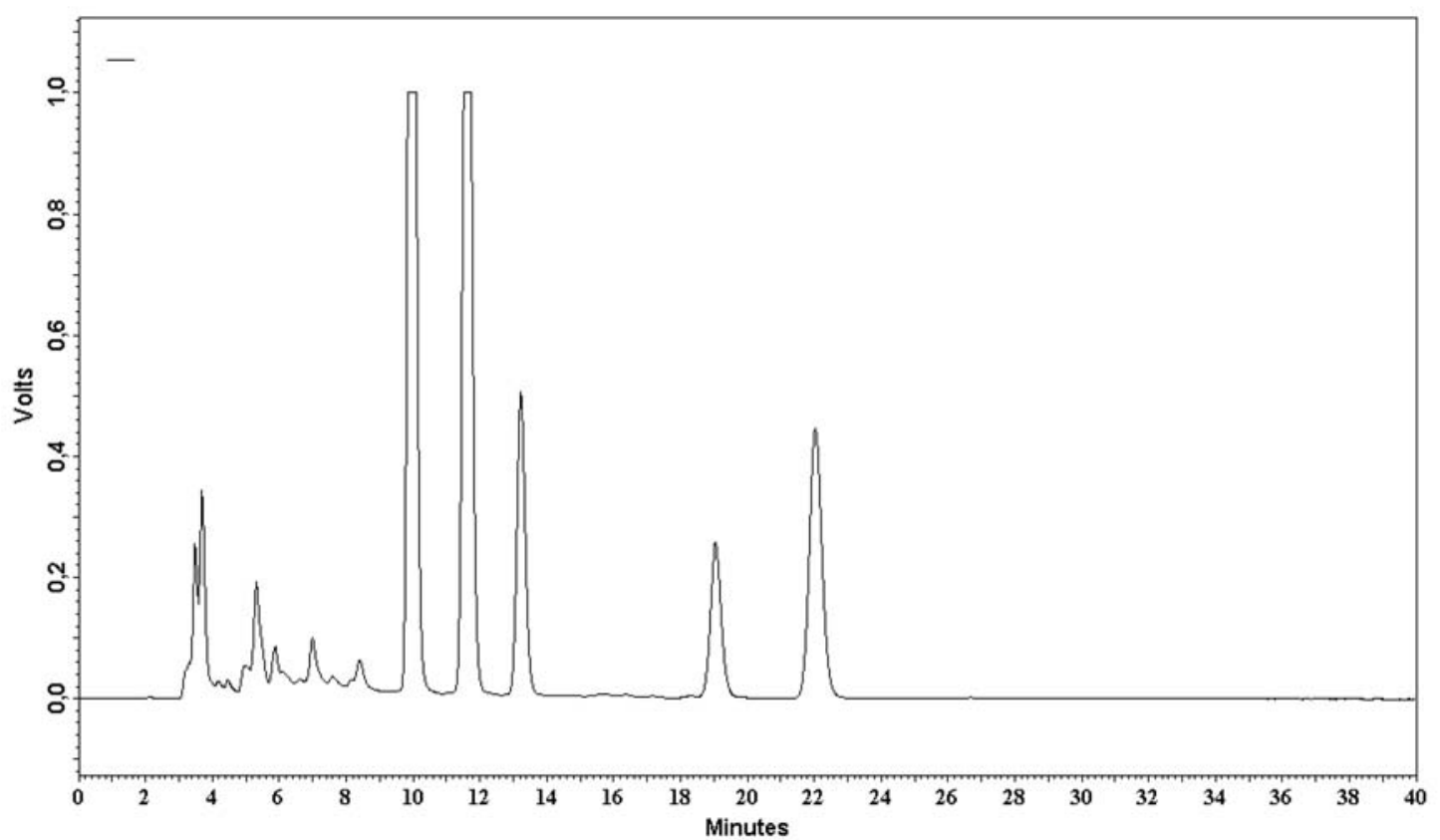

Figure S2. RP-HPLC-FLD chromatogram of tocopherols in inaja pulp.

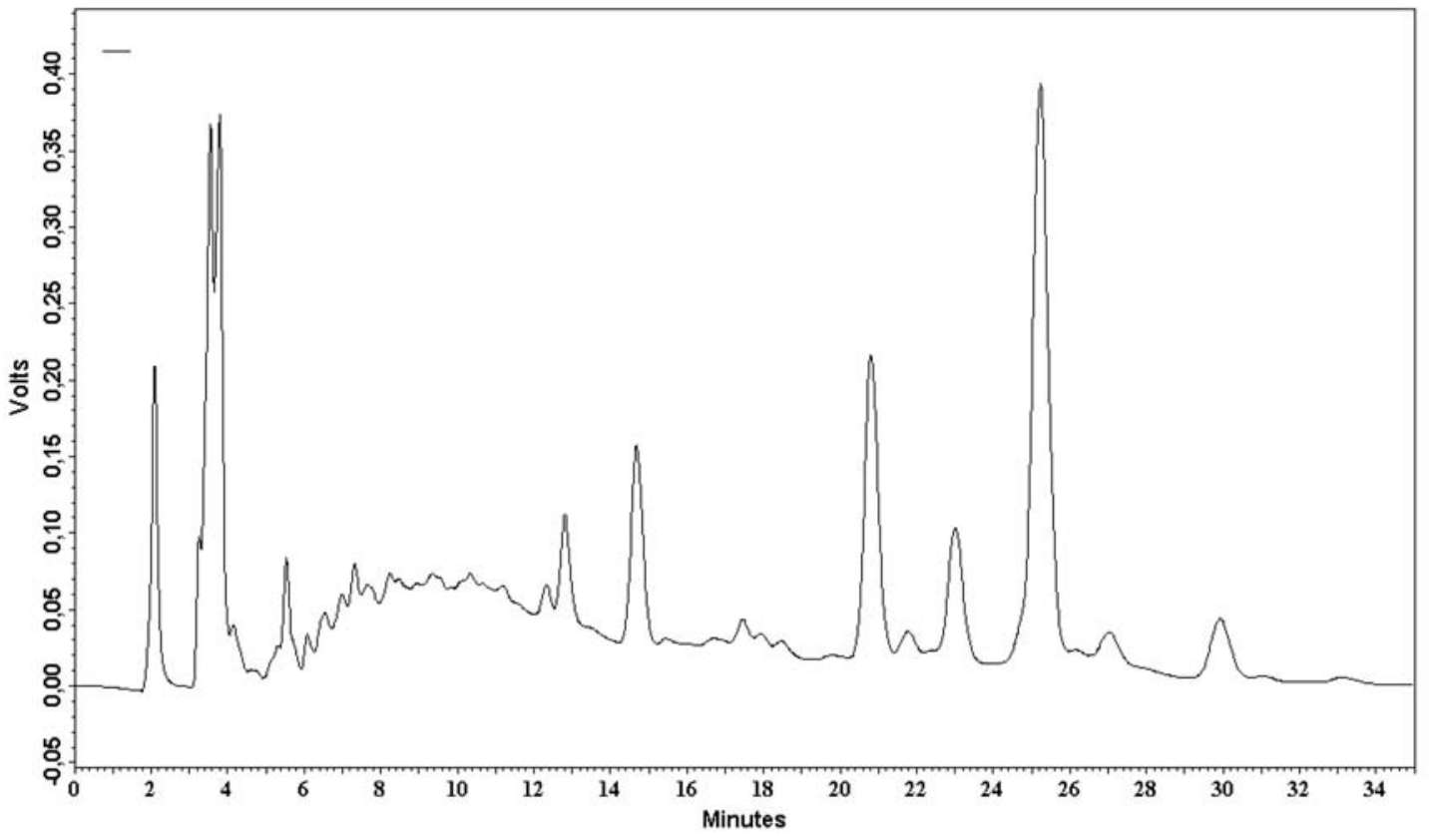

Figure S3. RP-HPLC-FLD chromatogram of tocopherols in patawa pulp. 


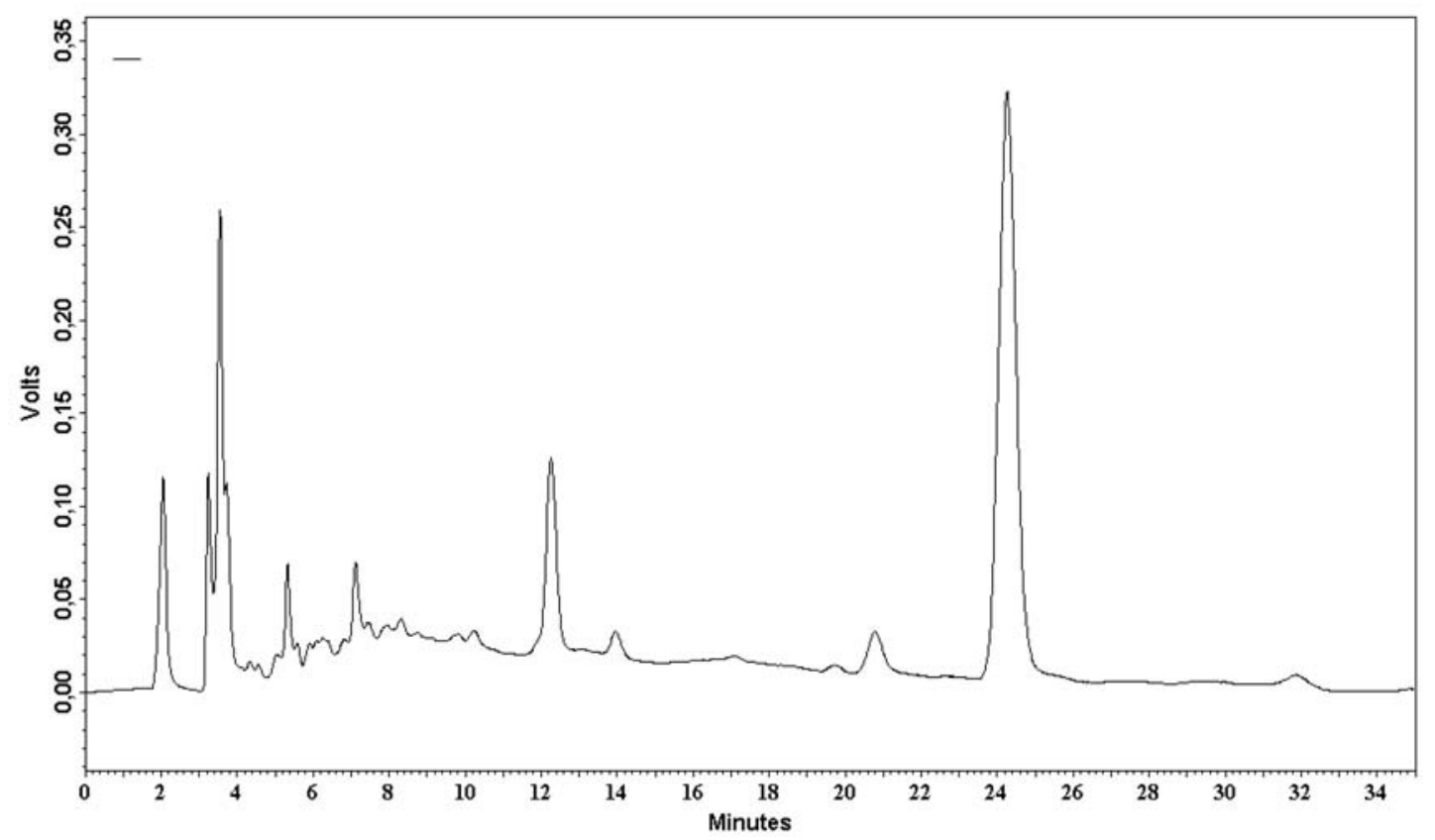

Figure S4. RP-HPLC-FLD chromatogram of tocopherols in tucuma pulp.

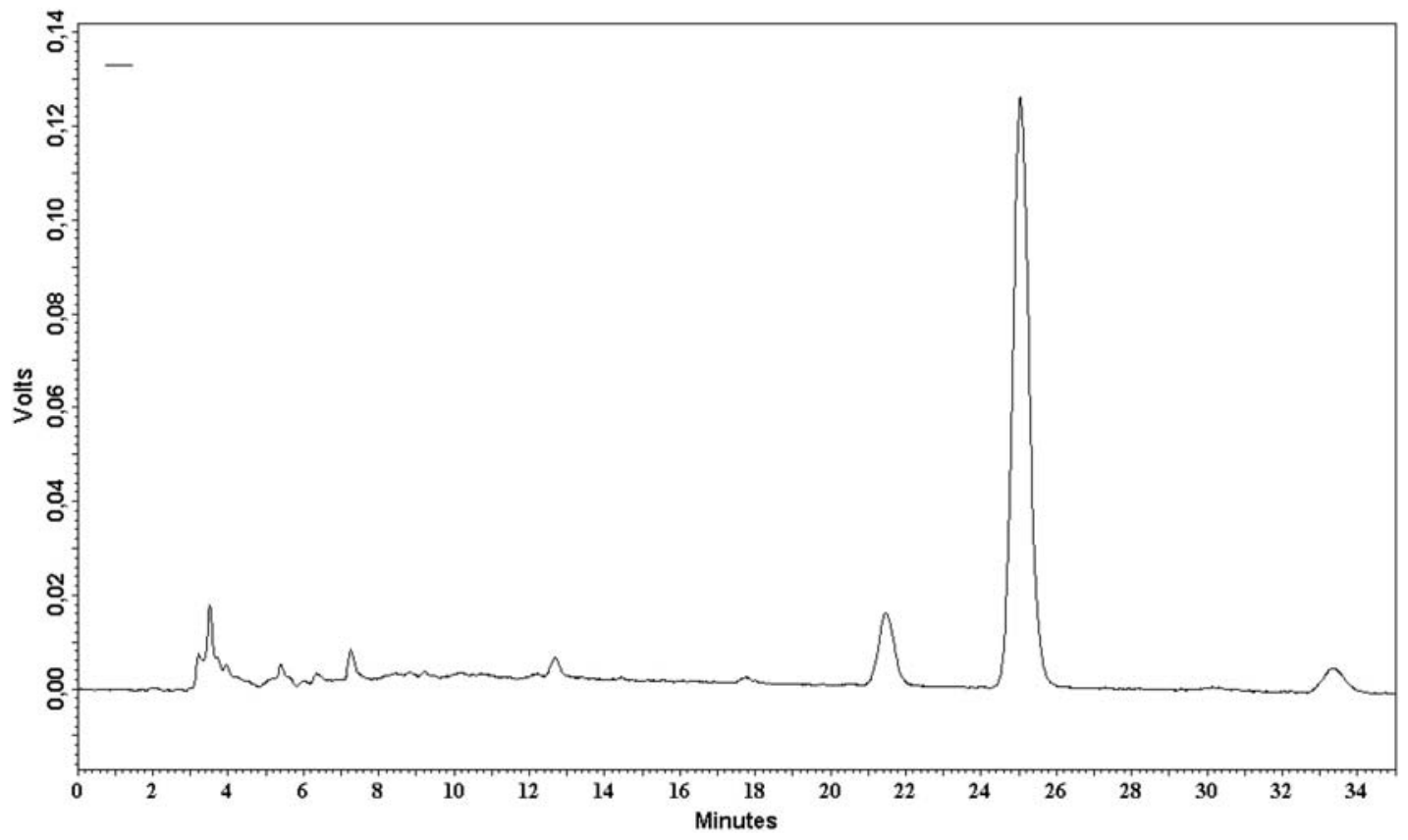

Figure S5. RP-HPLC-FLD chromatogram of tocopherols in mari pulp. 


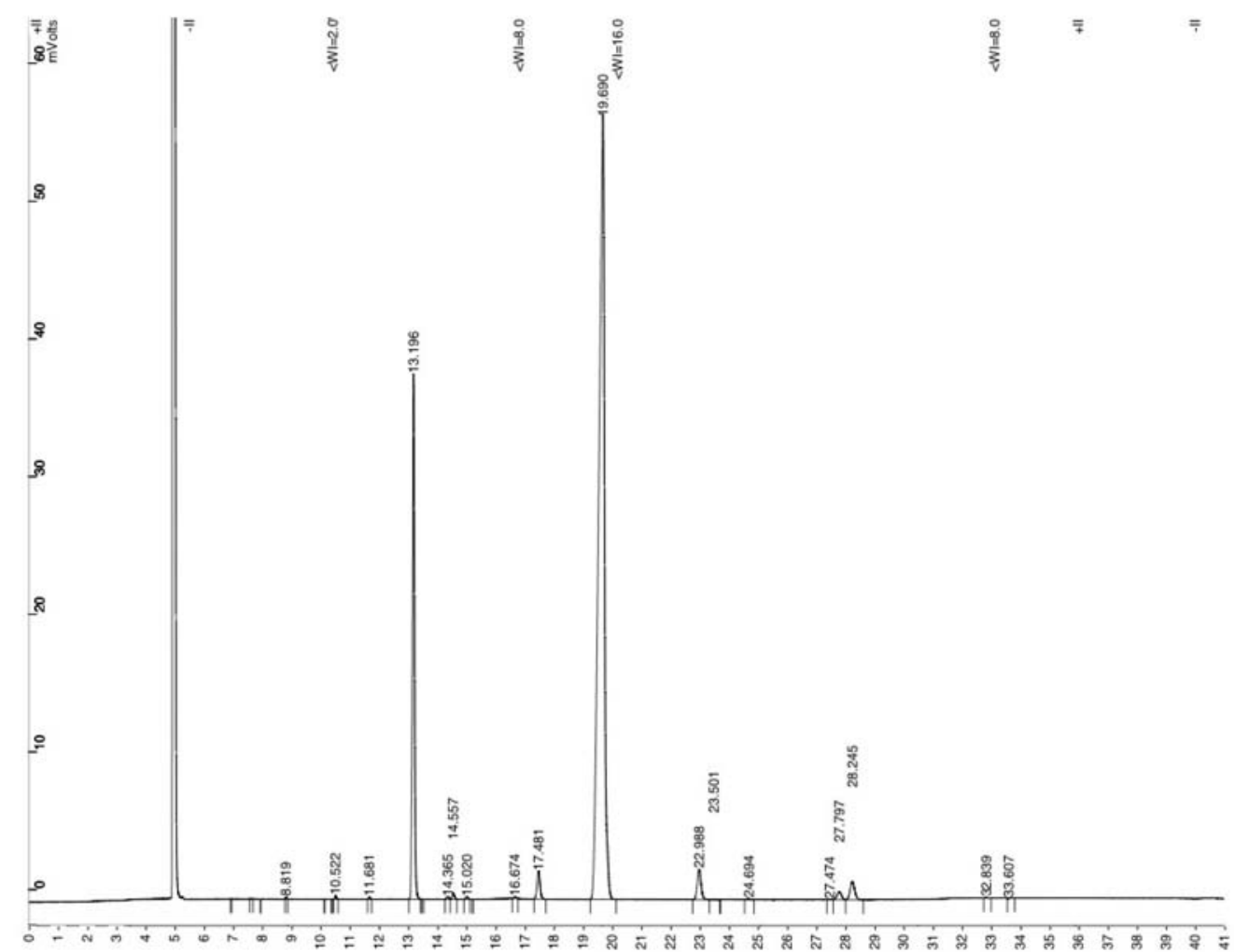

Figure S6. GC-FID chromatogram of fatty acids in buriti pulp.

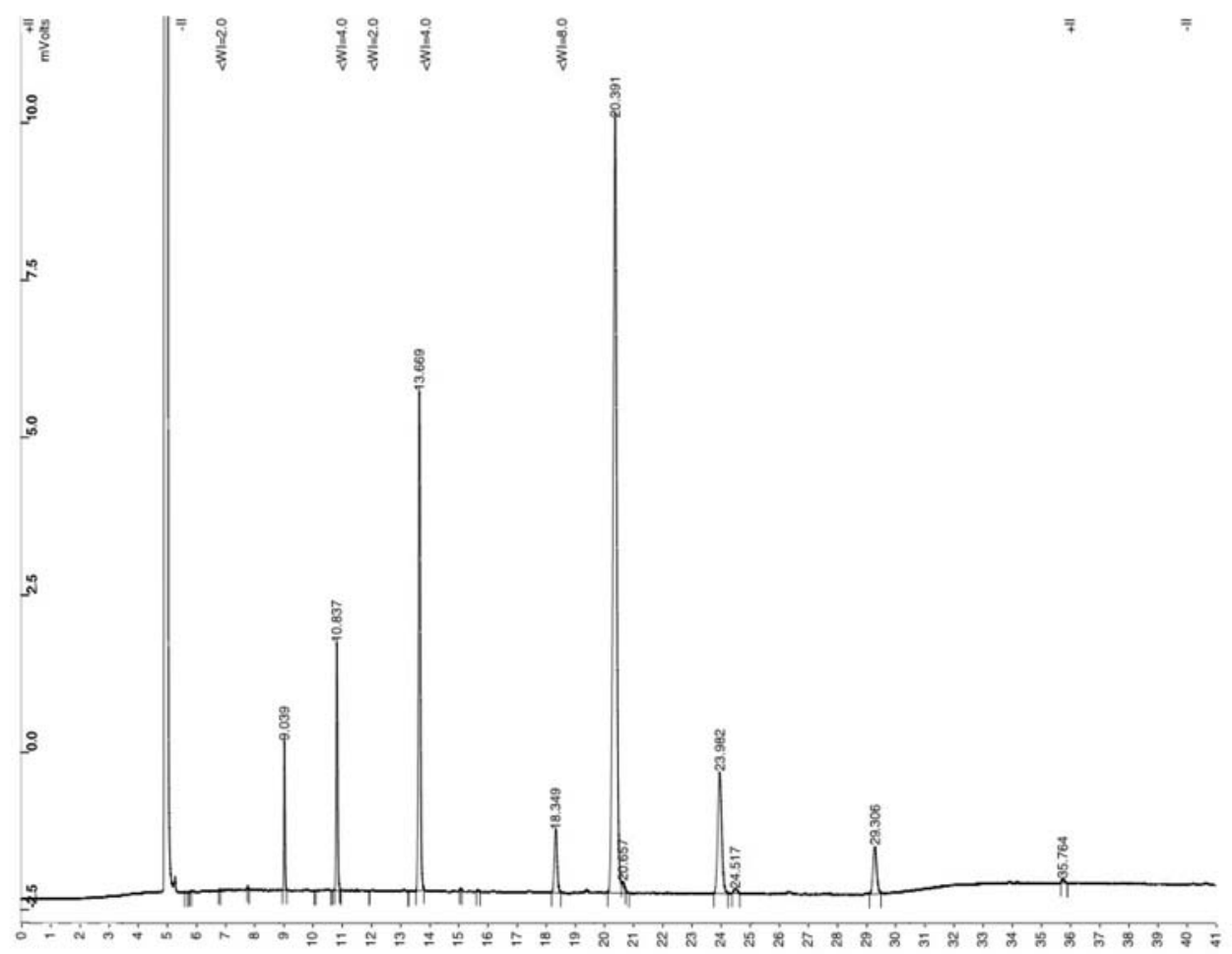

Figure S7. GC-FID chromatogram of fatty acids in inaja pulp. 


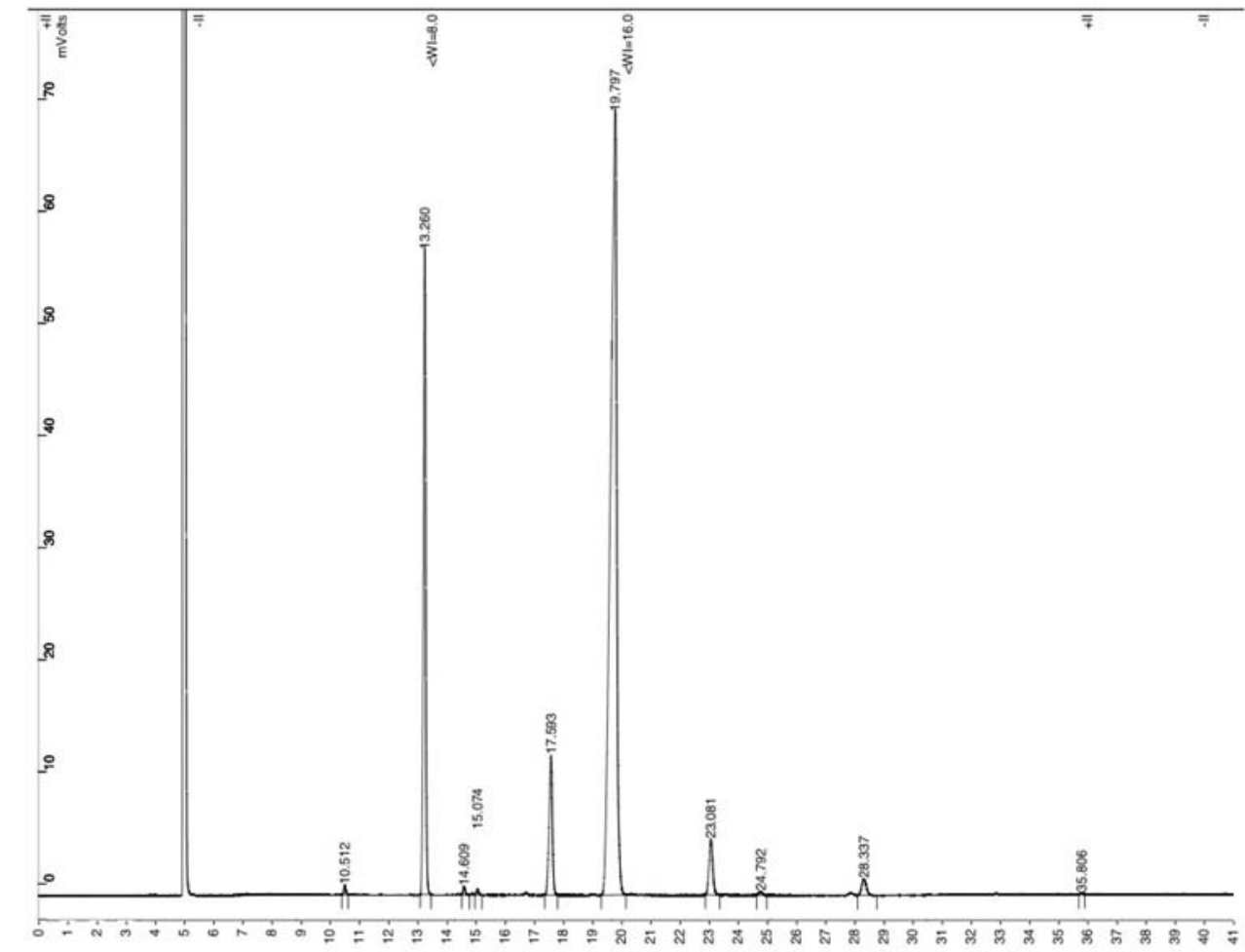

Figure S8. GC-FID chromatogram of fatty acids in mari pulp.

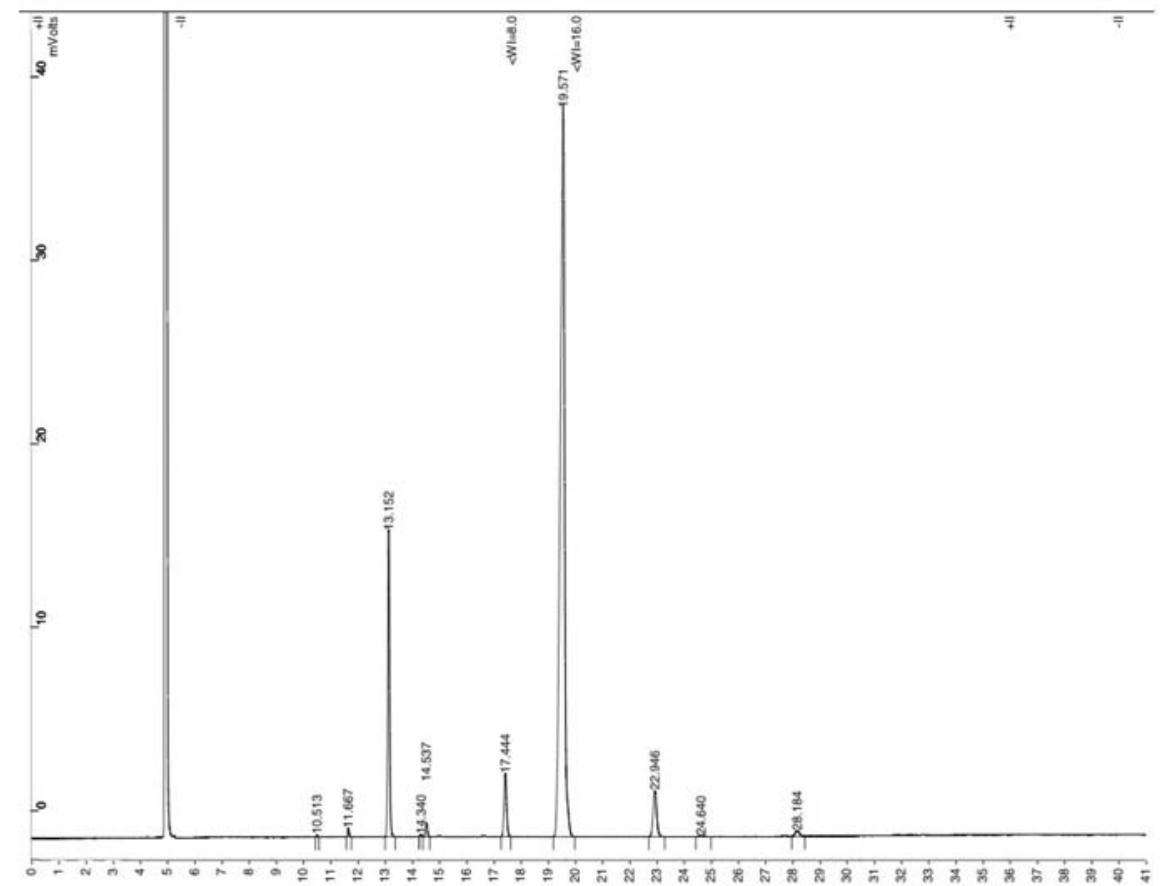

Figure S9. GC-FID chromatogram of fatty acids in patawa pulp. 


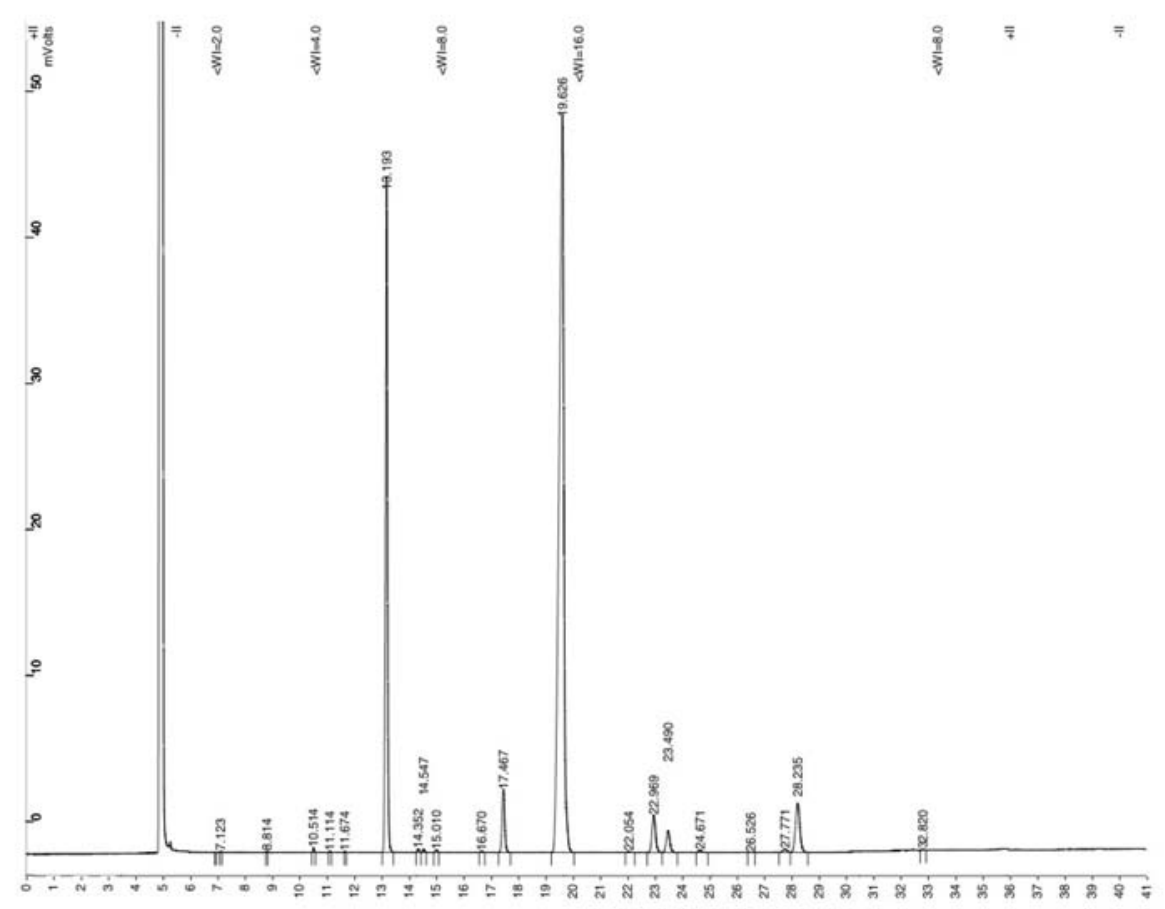

Figure S10. GC-FID chromatogram of fatty acids in tucuma pulp. 